\title{
Distribution and Incidence of Sphaeropsis Rot in Apple in Washington State
}

\author{
Y. K. Kim and C. L. Xiao, Department of Plant Pathology, Washington State University, Tree Fruit Research and \\ Extension Center, 1100 N. Western Avenue, Wenatchee, WA 98801
}

\begin{abstract}
Kim, Y. K., and Xiao, C. L. 2008. Distribution and incidence of Sphaeropsis rot in apple in Washington State. Plant Dis. 92:940-946.

Sphaeropsis rot, caused by Sphaeropsis pyriputrescens, is a recently recognized postharvest disease of apple in Washington State. To determine the distribution and incidence of this disease as well as other postharvest diseases, decayed fruit were sampled during packing or pre-sizing operations in commercial fruit packinghouses from 26, 72, and 81 grower lots in 2003, 2004, and 2005, respectively. Fungi associated with decayed fruit were isolated and identified. The most common postharvest diseases of apple in the region were blue mold caused by Penicillium spp., primarily $P$. expansum, gray mold caused by Botrytis cinerea, and Sphaeropsis rot, accounting for 32,28 , and $17 \%$ of the decayed fruit, respectively. Percentages of these diseases in the total decayed fruit varied from lot to lot. Bull's eye rot caused by Neofabraea spp. was responsible for $13.4 \%$ of the total decay and was most prevalent on Golden Delicious. Other minor diseases included speck rot caused by Phacidiopycnis washingtonensis, Alternaria rot caused by Alternaria spp., Mucor rot caused by Mucor piriformis, and core rot caused by a group of fungi, primarily Alternaria spp. Sphaeropsis stem-end rot was more common than calyx-end rot on Golden Delicious, whereas Sphaeropsis calyx-end rot was more common than stem-end rot on Fuji. On Red Delicious, both stem-end rot and calyx-end rot were common. Sphaeropsis rot resulting from infections through the fruit peel was more commonly seen on Golden Delicious and Fuji than on Red Delicious. The percentage of gray mold was higher on nondrenched fruit than on fruit drenched with thiabendazole (TBZ), whereas blue mold was more prevalent on TBZ-drenched fruit. Our results indicate that Sphaeropsis rot is an important component of storage rots of apples in Washington State.
\end{abstract}

Washington State is the leading producer of apples in the United States with over 3 billion kilograms grown in 2004, which made up $58 \%$ of the U.S. total production (20). In Washington State, Red Delicious, Fuji, and Golden Delicious are among the most commonly grown apple cultivars, accounting for 43,13 , and $12 \%$ of the total acreage, respectively (19). At harvest, apple fruit are hand-picked and placed into wooden or plastic bins, which are then transported to storage and packing facilities. Prior to storage, fruit may be drenched with diphenylamine (DPA; an antioxidant) in combination with thiabendazole (TBZ) to control superficial scald (a physiological disorder of the fruit peel) and postharvest diseases, respectively (18). Alternatively, fruit may not be drenched but instead treated with 1-methylcyclopropene (1-MCP), an inhibitor of ethylene action (3). 1-MCP was registered in 2002 in the United States for postharvest use on apples. 1-MCP inhibits apple fruit ripening process and thus retains fruit firmness (8), and also controls superficial scald of apple

Corresponding author: C. L. Xiao

E-mail:clxiao@wsu.edu

Accepted for publication 6 February 2008.

doi:10.1094/PDIS-92-6-0940

(C) 2008 The American Phytopathological Society fruit (9). Because 1-MCP is applied as a vapor treatment in storage rooms, some apple packers who apply 1-MCP have eliminated drench treatments with DPA and TBZ. Fruit are often stored in either regular atmosphere (RA) or controlled atmosphere (CA) (1 to $2 \% \mathrm{O}_{2}$ and $0.5 \%$ $\left.\mathrm{CO}_{2}\right)$ at -1 to $0^{\circ} \mathrm{C}(17)$. Fruit may be stored for up to 12 months before packing. Despite fungicides and improved storage technologies, postharvest fruit rot diseases still remain an important limiting factor for the long-term storage of apples (35).

Several postharvest diseases commonly occur on apples, including blue mold caused by Penicillium spp., primarily $P$. expansum (Link) Thom., gray mold caused by Botrytis cinerea Pers.:Fr., and bull's eye rot caused by Neofabraea spp. (6). Postharvest diseases of apple generally originate from two sources: infections through wounds at harvest or during the fruit handling and packing process, and latent fungal infections that occur in the orchards before harvest. Blue mold (22) and Mucor rot caused by Mucor piriformis E. Ficher (29) are examples of diseases in the first category. Diseases in the second category can be exemplified by bull's eye rot (28). Sphaeropsis rot, caused by Sphaeropsis pyriputrescens Xiao \& J.D. Rogers, is a recently recognized postharvest fruit rot disease of apple and pear. The disease was first found on pears (36). Later, it was observed that the disease caused more serious problems on apples (37). Although the basic biology of $S$. pyriputrescens has been described (14), little is known about the disease.

The objectives of this study were to determine (i) the prevalence and incidence of Sphaeropsis rot and other common postharvest diseases on apples grown in Washington State; (ii) the infection sites of Sphaeropsis rot on apple fruit; and (iii) the occurrence of postharvest diseases under different postharvest handling systems.

\section{MATERIALS AND METHODS}

Packinghouse surveys. Surveys of Sphaeropsis rot and other postharvest diseases in stored apples were conducted in 2003, 2004, and 2005. Decayed apple fruit were sampled from six commercial packinghouses, representing orchards in various apple-producing areas in Washington State, including north-central Washington, the Columbia Basin, and the Yakima area. Approximately 50 decayed fruit from each grower lot were randomly sampled from cull bins or sorting tables during packing or pre-sizing operations in the packinghouses. In this study, each grower lot represented fruit harvested from one orchard. Twenty-six grower lots (cv. Red Delicious) were sampled during June to August in 2003; 72 grower lots (39 Red Delicious, 19 Golden Delicious, and 14 Fuji) and 81 grower lots (37 Red Delicious, 19 Golden Delicious, and 25 Fuji) were sampled from March to August in 2004 and 2005, respectively. In addition, percent losses of fruit due to decays during storage were estimated by examining 400 arbitrarily selected fruit per grower lot in 2005. Information on the location of the orchard and postharvest treatments for each grower lot was obtained from the packers.

Decayed fruit were transported to the laboratory on the same day they were collected from the packinghouses and stored at $4^{\circ} \mathrm{C}$. Samples were sorted by symptoms and the presence of wounds. Color of decayed areas and type of decay (soft or watery decay versus firm or spongy decay) were also recorded. Photos of all decayed fruit were taken before isolation in order to correlate causal agents with the disease symptoms they incited.

Isolation and identification of causal agents. Identification of causal agents was made based on the pathogen signs and morphology of fungi under a microscope if sporulation or fruiting bodies of the pathogens were present on decayed fruit. Otherwise, isolations were made from all rot- 
ten fruit. After surface-sterilization with $70 \%$ ethanol, small fragments of the fruit flesh were removed from the margin of decayed and healthy tissue with a sterile scalpel and placed on acidified potato dextrose agar (APDA; Difco Laboratories, Detroit, MI) $(4.0 \mathrm{ml}$ of a $25 \%$ solution of lactic acid per liter of medium). Dishes were incubated at $20^{\circ} \mathrm{C}$ in the dark and examined for culture development. Fungi that grew on APDA were transferred to fresh APDA. Pure cultures were then grown on PDA. Identification of S. pyriputrescens was based upon the descriptions of the fungus by Xiao and Rogers (36). Identification of Phacidiopycnis spp. were made following the descriptions by Xiao et al. (38). Identification of other fungi was based on descriptions by Barnett and Hunter (1), Carmichael et al. (4) for hyphomycetes, and Sutton (31) for coelomycetes.

Data analysis. Analysis of variance was performed with SAS PROC GLM (Version 9.1, SAS Institute, Cary, NC) to compare percentage of Sphaeropsis rot originating from different infection sites followed by mean separation within a cultivar by Fisher's protected least significant difference (LSD, $P=0.05$ ). To compare TBZdrenched fruit with nondrenched fruit for each disease, percentage of decay was compared by a $t$ test using SAS PROC TTEST $(P=0.05)$. All percentage data were arcsine-transformed prior to analysis (10). Linear regression was performed on progression of Sphaeropsis stem and calyx rot on Red Delicious apples in relation to storage time using SAS PROC REG.

\section{RESULTS}

Occurrence of Sphaeropsis rot and other postharvest diseases. Over the 3year survey, Sphaeropsis rot accounted for $16.9 \%$ of decayed fruit. Blue mold caused by Penicillium spp., primarily $P$. expansum, and gray mold caused by $B$. cinerea accounted for 31.7 and $28.1 \%$ of the decayed fruit, respectively (Table 1). Although there was variability among cultivars and years, Sphaeropsis rot occurred on all three cultivars in all 3 years and accounted for $>20 \%$ of the total decay on Red Delicious. Blue mold was the most common disease on Red Delicious in 2003 and 2004, and on Fuji in 2005. Gray mold was most common on Fuji in 2004 and Red Delicious in 2005. Bull's eye rot was responsible for $13.4 \%$ of the total decayed fruit; however, it was much more common on Golden Delicious than on Red Delicious or Fuji, accounting for 30 and $44 \%$ of the total decayed fruit of Golden Delicious in 2004 and 2005, respectively. Speck rot caused by Phacidiopycnis washingtonensis Xiao \& J.D. Rogers $(13,38)$, Alternaria rot caused by Alternaria spp., and Mucor rot caused by Mucor piriformis accounted for $2.2,1.7$, and $0.6 \%$ of the total decay, respectively. Other diseases included Aureobasidium rot caused by Aureobasidium pullulans (deBary) G. Arnaud, core rot caused by a group of fungi, primarily Alternaria spp., Cladosporium rot caused by Cladosporium herbarum (Pers.:Fr.) Link, Phacidiopycnis rot caused by Potebniamyces pyri (Berk. \& Broome) Dennis (34), black rot caused by Botryosphaeria obtusa (Schwein.) Shoemaker (32), Cytospora rot caused by Cytospora spp., and other minor rots caused by unidentified fungi, accounting for $5.4 \%$ of the total decay.

In 2005, losses of fruit due to decays in 78 grower lots were determined. The average incidence of decayed fruit was significantly lower on TBZ-drenched fruit $(1.9 \%$ ranged from 0.25 to $10 \%$ ) than on nondrenched fruit $(5.1 \%$ ranged from 1 to 25\%) $(P=0.0006)$.

Distribution and prevalence of Sphaeropsis rot. Sphaeropsis rot was found in fruit from all seven counties where we sampled (Fig. 1). Percentage of orchards with Sphaeropsis-infected fruit ranged from 32 to $100 \%$ with an average of $73 \%$. Percentage of Sphaeropsis rot in the decayed fruit within a grower lot varied from lot to lot (Fig. 2). Sphaeropsis rot comprised $>20 \%$ of the decayed fruit in $30 \%$ of the grower lots in the 3-year average and accounted for $>75 \%$ of the decayed fruit in $8 \%$ of the lots, which was slightly higher than that of either gray mold or blue mold. Severe Sphaeropsis rot was observed in Red Delicious and Fuji apples in some grower lots in 2003 and 2005 , respectively. In one grower lot in $2003,24 \%$ of the Red Delicious apples had Sphaeropsis rot after 9 months of storage in CA. Approximately 15 to $20 \%$ of the fruit were infected by $S$. pyriputrescens after 10 months of storage in another Red Delicious grower lot. Ninety-six, 77, and $61 \%$ of the grower lots were infected by $S$. pyriputrescens, and 4 (16\%), 16 (28\%), and $11(22.5 \%)$ grower lots that had Sphaeropsis-infected fruit showed a high level of incidence ( $>40 \%$ in the total decay) in 2003, 2004, and 2005, respectively.

Gray mold, blue mold, and bull's eye rot. In all 3 years of the survey, gray mold and blue mold commonly occurred (Fig. 2). More than $95 \%$ of the grower lots had fruit that was infected by $B$. cinerea. Blue mold also was observed in more than $90 \%$ of the grower lots. Percentages of gray mold and blue mold in the total decay varied among lots sampled. In 2003, all 26 grower lots had fruit infected by $B$. cinerea, which accounted for more than $40 \%$ of the total decayed fruit in $46 \%$ of the grower lots. Gray mold comprised $>20 \%$ of the decayed fruit in $51 \%$ of the lots in the 3-year average. Blue mold comprised $>20 \%$ of the decayed fruit in $63 \%$ of the lots in the 3-year average. Bull's eye rot was observed in 50 to $60 \%$ of the grower

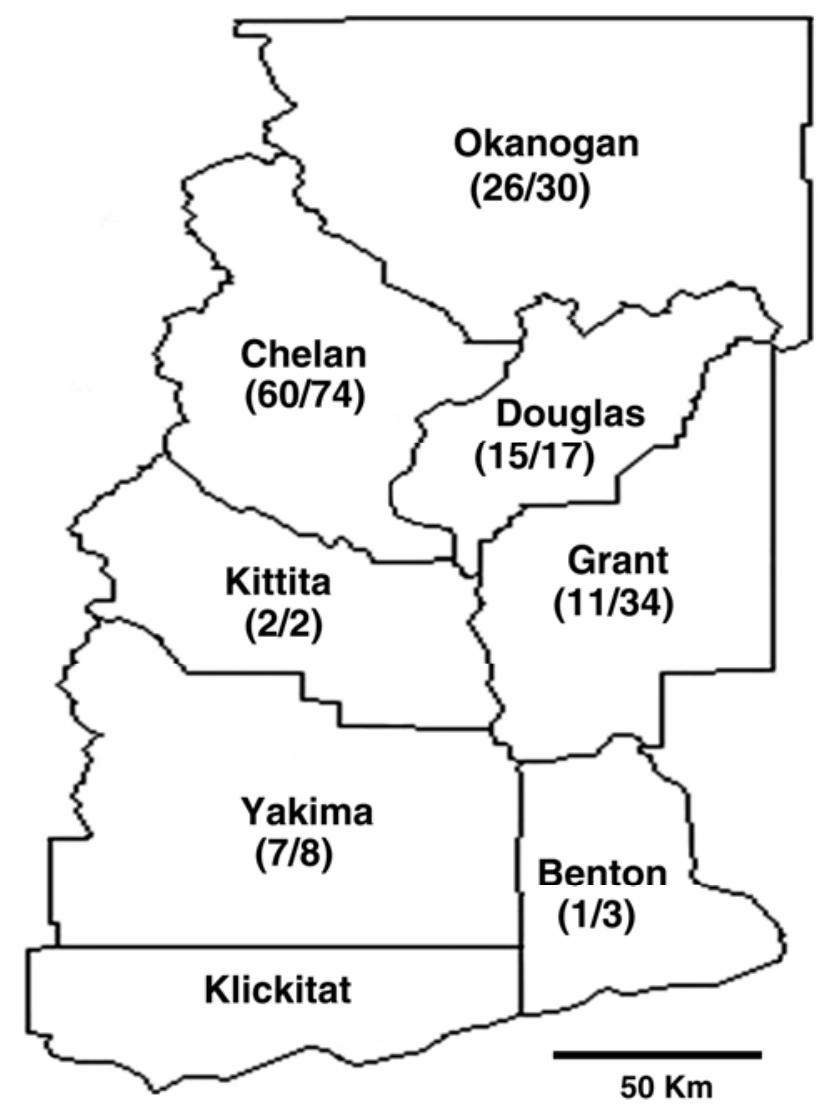

Fig. 1. Distribution of Sphaeropsis rot in central Washington State. Numbers in parentheses indicate number of grower lots with apples infected by the fungus over the total number of samples in the county collected from 2003 to 2005 . 
lots, but most infected grower lots had low levels of bull's eye rot $(<10 \%$ in the total decay). However, high levels of bull's eye rot were observed in 2004 and 2005, mainly on Golden Delicious (Table 1 and Fig. 2).
Infection sites of Sphaeropsis rot. $S$. pyriputrescens was associated with three types of symptoms: stem-end rot, calyxend rot, and skin rot. The skin rot includes infections through the peel of the fruit and those from fruit-to-fruit spread in storage


\section{Percentage of the total decayed fruit within a grower lot}

Fig. 2. Percentage of grower lots with different levels of Sphaeropsis rot, gray mold, blue mold, and bull's eye rot expressed as percentages of the total decayed apple fruit within a grower lot collected from 2003 to 2005 . Twenty-six, 72 , and 81 samples of approximately 50 decayed fruit each were collected in 2003, 2004, and 2005, respectively. Each sample represents the fruit from one unique orchard. bins under high relative humidity. Sphaeropsis rot mainly originated from infections of either the stem or calyx of the fruit; however, the infection site was cultivar-specific (Fig. 3). On Golden Delicious, $55 \%$ of Sphaeropsis rot originated from stem infections, which was significantly higher than calyx or skin infections $(P=$ 0.006). On Fuji, calyx infection was more common than stem infection $(P=0.022)$. There was no difference between stem and calyx infections of Sphaeropsis rot on Red Delicious. Skin infections were common on Golden Delicious (32\%), whereas only $2 \%$ of the infections originated through the skin on Red Delicious. The skin infection on Fuji was intermediate between Golden Delicious and Red Delicious. On Red Delicious, percentage of stem-end rot in the Sphaeropsis-infected fruit increased as the period of storage lengthened, whereas the percentage of calyx-end rot decreased as the period of storage lengthened (Fig. 4). The symptoms of skin infection were not observed until 8 months after harvest on Red Delicious. On Golden Delicious and Fuji, symptoms of Sphaeropsis rot resulting from skin infection were observed as early as 6 and 5 months after harvest, respectively, when the first sampling started.

Postharvest diseases under different postharvest-handling systems. The pattern of occurrence of postharvest diseases under different postharvest handling systems was very similar in all 3 years (Fig. 5 ). The percentage of gray mold in the total decay was higher on nondrenched fruit than on TBZ-drenched fruit, whereas blue mold was more prevalent on TBZdrenched fruit than on nondrenched fruit $(P<0.05)$. There was no difference in percent Sphaeropsis rot between nondrenched and TBZ-drenched fruit $(P>$ $0.54)$. On TBZ-drenched fruit, the incidence of blue mold was the highest followed by either gray mold or Sphaeropsis rot. On nondrenched fruit, gray mold comprised the highest percentage of the total decay followed by blue mold and Sphaeropsis rot. Bull's eye rot comprised $<5 \%$ of the total decay with an exception of the nondrenched fruit in 2004. There was no difference in bull's eye rot between nondrenched and TBZ-drenched fruit in 2003 and $2005(P>0.14)$, while nondrenched fruit showed a higher percentage of bull's eye rot than TBZ-drenched fruit in $2004(P<0.05)$.

\section{DISCUSSION}

This is the first report on the distribution and incidence of Sphaeropsis rot in apple. We found that it was widely distributed in all major apple-growing counties in Washington State. Over the 3-year survey of postharvest diseases in stored apples, Sphaeropsis rot occurred in approximately $78 \%$ of the grower lots sampled and accounted for an average of $17 \%$ of the decayed fruit. We also observed several in- 
stances of severe Sphaeropsis infection in Red Delicious and Fuji grower lots. Although we observed Sphaeropsis rot on Gala and Granny Smith apples, these two cultivars were not included in this study because of limited availability of fruit for sampling in the later storage season. Our results indicate that Sphaeropsis rot is one of the important postharvest diseases in apple in Washington State.

According to a report published in 1931 (11), 90 species of fungi are associated with fruit rots in stored apples, and more than 40 species in 22 genera are responsible for them in Washington State. Additional pathogens have been reported since that time (6). Because no detailed surveys of postharvest diseases in apple have been conducted in this region since the 1931 report, it is unknown whether $S$. pyriputrescens was recently introduced or has been present in the region for a long time. However, a high percentage of grower lots with infected fruit and distribution of the fungus in a large geographic area suggest that Sphaeropsis rot has been established in the region for years without being recognized.

Among the fruit rot diseases observed in our survey, in addition to Sphaeropsis rot, two other postharvest diseases were recently reported in the United States: Phacidiopycnis rot and speck rot. Sphaeropsis rot was first found on d'Anjou pears during a survey for postharvest diseases of pears in Washington State (36), but its incidence in pear fruit was not as severe as in apple fruit, as reported in this study (34). Phacidiopycnis rot is one of the major postharvest diseases affecting d'Anjou pears grown in the Wenatchee River Valley, WA, the primary production area for d'Anjou pears in the nation (34), but it was a very minor disease in apple, as we found in this study. Instances of severe losses resulting from speck rot have been reported in Red Delicious apples (13), but

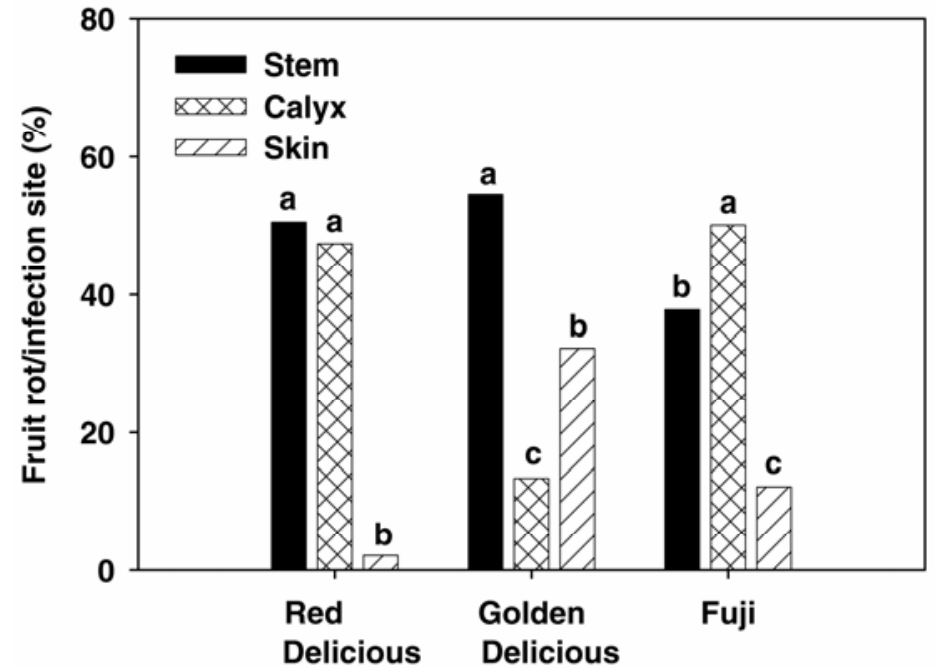

Fig. 3. Percentage of Sphaeropsis rot originating from infection at stem, calyx, and skin by Sphaeropsis pyriputrescens in apples sampled from 2003 to 2005 for Red Delicious and from 2004 and 2005 for Golden Delicious and Fuji. Bars with different letters within the same cultivar are significantly different according to Fisher's least significant difference $(P=0.05)$.

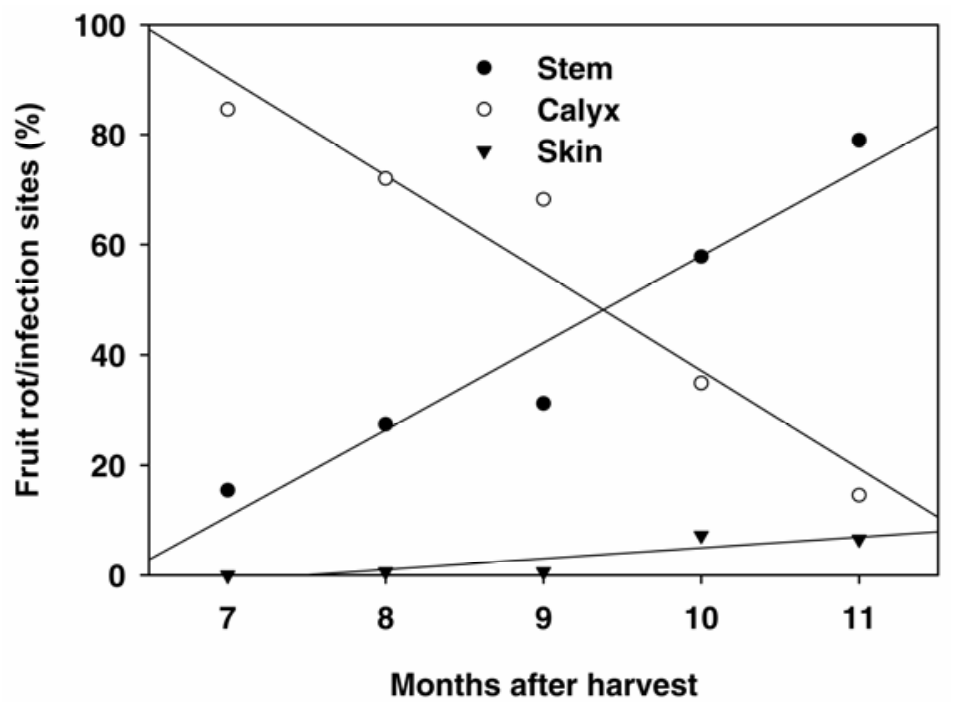

Fig. 4. Percentage of Sphaeropsis rot after various times in storage originating from infection at stem $\left(y=-0.83+0.17 x, R^{2}=0.95\right)$, calyx $\left(y=2.58-0.19 x, R^{2}=0.94\right)$, and skin $\left(y=-0.5+0.07 x, R^{2}=\right.$ 0.86 ) by Sphaeropsis pyriputrescens in apples cv. Red Delicious sampled from 2003 to 2005.

Table 1. Mean percentages of postharvest fruit rots caused by various pathogens in the total decayed apple fruit sampled from commercial packinghouses in Washington State from 2003 to 2005

\begin{tabular}{|c|c|c|c|c|c|c|c|c|c|c|}
\hline Year & Cultivar & $\begin{array}{l}\text { No. of } \\
\text { grower lots }\end{array}$ & $\begin{array}{c}\text { Sphaeropsis } \\
\operatorname{rot}\end{array}$ & $\begin{array}{l}\text { Gray } \\
\text { mold }\end{array}$ & $\begin{array}{l}\text { Blue } \\
\text { mold }\end{array}$ & $\begin{array}{c}\text { Bull's eye } \\
\text { rot }\end{array}$ & $\begin{array}{c}\text { Speck } \\
\text { rot }^{\mathrm{b}}\end{array}$ & $\begin{array}{l}\text { Mucor } \\
\text { rot }\end{array}$ & $\underset{\text { rot }^{\mathbf{c}}}{\text { Alternaria }}$ & Others $^{\mathrm{d}}$ \\
\hline 2003 & Red Delicious & 26 & 23.6 & 34.0 & 35.2 & 3.5 & 0.7 & 0.0 & 0.0 & 3.0 \\
\hline \multirow[t]{4}{*}{2004} & Red Delicious & 39 & 21.7 & 23.7 & 41.4 & 2.8 & 6.5 & 0.4 & 0.8 & 2.7 \\
\hline & Golden Delicious & 19 & 18.0 & 29.9 & 18.8 & 30.0 & 0.2 & 0.0 & 1.2 & 1.9 \\
\hline & Fuji & 14 & 18.8 & 32.2 & 30.2 & 4.9 & 2.0 & 0.9 & 2.8 & 8.2 \\
\hline & Mean & & 19.5 & 28.6 & 30.1 & 12.6 & 2.9 & 0.4 & 1.6 & 4.3 \\
\hline \multirow{5}{*}{2005} & Red Delicious & 37 & 20.2 & 36.4 & 27.9 & 2.8 & 4.8 & 0.8 & 1.3 & 5.8 \\
\hline & Golden Delicious & 19 & 9.4 & 22.9 & 17.5 & 43.8 & 0.0 & 0.3 & 2.0 & 4.1 \\
\hline & Fuji & 25 & 6.3 & 17.7 & 50.6 & 5.7 & 1.5 & 2.1 & 3.7 & 12.4 \\
\hline & Mean & & 12.0 & 25.7 & 32.0 & 17.4 & 2.1 & 1.1 & 2.3 & 7.4 \\
\hline & Overall mean ${ }^{\mathrm{e}}$ & & 16.9 & 28.1 & 31.7 & 13.4 & 2.2 & 0.6 & 1.7 & 5.4 \\
\hline
\end{tabular}

${ }^{a}$ Each grower lot represents the fruit from one unique orchard. Apples were stored in bins in controlled or regular atmosphere. Approximately 50 decayed fruit from each lot were collected from cull bins or sorting tables depending on packing or pre-sizing operations.

${ }^{\mathrm{b}}$ Data on speck rot have been published (13) but are included here for comparison.

${ }^{\mathrm{c}}$ Alternaria rot is caused by Alternaria spp.

${ }^{\mathrm{d}}$ Includes: Aureobasidium rot caused by A. pullulans; core rot caused by a group of fungi, primarily Alternaria spp.; Cladosporium rot caused by $C$. herbarum; Phacidiopycnis rot caused by Potebniamyces pyri; black rot caused by Botryosphaeria obtusa; Cytospora rot caused by Cytospora spp., and other minor rots caused by unidentified fungi.

e Overall mean is the average of all cultivars in all 3 years. 
speck rot was not observed on d'Anjou pears during a survey of postharvest diseases of pears conducted during 2001 and 2002 (34). One common characteristic of these three diseases is their association with cankers and twig dieback of trees in orchards (33). The recent discovery of these three diseases also suggests that a periodic survey of postharvest diseases is necessary, particularly when orchard and postharvest practices have changed. For example, changes in fungicide use in the orchard and packinghouse may affect populations of decay-causing pathogens and thus the diseases.

The pattern of occurrence of postharvest diseases was very similar in all 3 years of our survey. Blue mold, gray mold, and Sphaeropsis rot were the three major postharvest diseases in apple cultivars Fuji and Red Delicious. Bull's eye rot was more prevalent on Golden Delicious than on other cultivars we examined. Sholberg and Haag (27) surveyed postharvest diseases of apples in British Columbia (B.C.), Canada from 1991 to 1993 and reported that blue
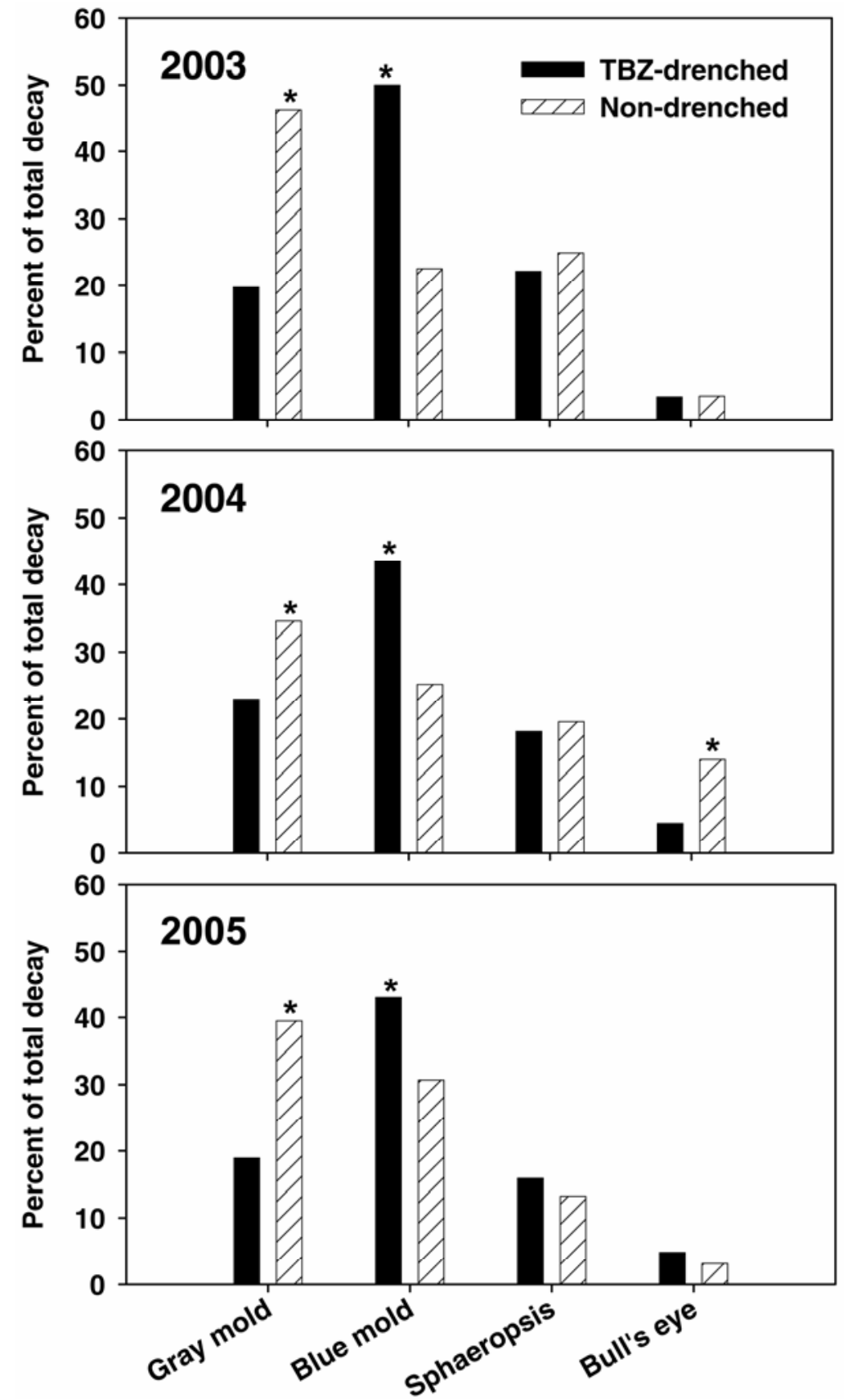

Fig. 5. Percentage of postharvest diseases caused by various pathogens on thiabendazole-drenched and nondrenched fruit collected from 2003 to 2005. Twenty-six (Red Delicious), 72 (39 Red Delicious, 19 Golden Delicious, and 14 Fuji), and 62 (37 Red Delicious and 25 Fuji) samples of approximately 50 decayed fruit each were collected in 2003, 2004, and 2005, respectively. Golden Delicious sampled in 2005 was not included due to the lack of nondrenched fruit. For each disease, an asterisk on the top of a bar indicates a significant difference between thiabendazole-drenched and nondrenched fruit based on the $t$ test $(P=0.05)$.

mold and gray mold are the most common postharvest diseases of apple in the region, which is consistent with our results. However, they also reported that Mucor rot was an important postharvest disease, accounting for $22 \%$ of the total decayed fruit. The highest Mucor rot we observed in our survey was $9.8 \%$ in a Fuji grower lot in 2005 ; overall mean Mucor rot over the 3-year survey was only $0.6 \%$. The difference in results between B.C. and our study may be due to differences in sample size and cultivar. Sholberg and Haag (27) sampled a total of 554 fruit, while we sampled approximately 9,000 fruit from 179 grower lots over 3 years. They observed a high relative incidence of Mucor rot (47.6\%) on the cultivar Jonagold; however, this cultivar was not included in our survey. In this study, the percentage of grower lots with different levels of major postharvest diseases varied from orchard to orchard. It appeared that the occurrence of postharvest diseases was orchard- or lot-specific.

Infection of apple fruit by S. pyriputrescens appeared to occur in the orchards rather than after harvest in the packinghouses. We observed Sphaeropsis rot on fruit in 60 of 82 grower lots $(73 \%)$ that had not been drenched with DPA and/or TBZ after harvest before they were put in storage. Thus, contamination of fruit by the fungus during postharvest drench can be ruled out. This evidence supports the hypothesis that infection of fruit by $S$. pyriputrescens occurs in the orchard prior to storage. Stem-end rot and calyx-end rot were the two common symptoms of Sphaeropsis rot on all three apple cultivars we sampled. Stem-end rot was dominant on Golden Delicious, while calyx-end rot dominated on Fuji. Although Sphaeropsis rot resulting from infections of fruit skin or from fruit-to-fruit spread also was observed, it occurred more often on Golden Delicious than on the other two cultivars. It is unknown when and how infections on different infection sites occur in the orchard. In general, symptoms of calyx infection develop earlier than stem infection even if both sites are infected by the fungus on the same fruit. In a fruit inoculation study (Y. K. Kim and C. L. Xiao, unpublished), most calyx-end rots originated from infected sepals and stem-end rots originated from infections of the peduncle. Once the fungus colonized the stem, it grew down very slowly toward the stem-bowl area before reaching the fruit flesh to cause symptoms on the fruit; thus, symptoms on fruit resulting from infections of the stem often appeared later than those resulting from infections of the calyx. It is unknown why stemend rot is more common on Golden Delicious than calyx-end rot. The relationship between factors contributing to susceptibility of the stem and calyx to infection by $S$. pyriputrescens and development of Sphaeropsis rot in storage on different cultivars remains to be determined. 
Although different postharvest treatments altered the proportion of major diseases in a sample, a postharvest drench with TBZ significantly reduced losses of fruit due to rots compared with the nondrenched treatment as we examined in 2005. The nondrenched treatment included fruit either treated with 1-MCP or not treated with any chemicals. Several studies have reported the effects of 1-MCP on postharvest diseases of pome fruits; however, the results have been inconsistent. Janisiewicz et al. (12) and Saftner et al. (24) reported that 1 -MCP in combination with an antagonist and/or heat treatments effectively controlled postharvest diseases on Golden Delicious apples including blue mold, gray mold, and bitter rot. However, blue mold and bitter rot increased in apple fruit treated with 1-MCP alone (12). Spotts et al. (30) reported that a combination of 1-MCP and hexanal, a naturally occurring volatile, may reduce storage decays on d'Anjou pear fruit. However, they suggested that 1-MCP should not be relied on to give adequate control of postharvest diseases. In our surveys, the number of grower lots that were treated with $1-\mathrm{MCP}$ varied from 0 to 16 among the lots we sampled each year. Because of the limited number of sampled lots treated with 1-MCP, we did not separate 1-MCP treatment from the nondrenched treatment and did not examine the effects of 1-MCP on the occurrence of postharvest diseases.

It appeared that a postharvest drench with TBZ prior to storage did not alter the occurrence of Sphaeropsis rot. In a study using naturally infected fruit and inoculated fruit, a postharvest TBZ-drench was effective in controlling Sphaeropsis rot (C. L. Xiao, unpublished data). Thus, TBZdrench may not change the proportion of Sphaeropsis rot in the total decayed fruit but may reduce the actual losses of fruit caused by this disease. In our survey, the fruit that had been drenched with TBZ had a significantly lower percentage of gray mold in the total decay than the nondrenched fruit in all 3 years. This is in agreement with the report by Lennox et al. (15) that a postharvest TBZ-drench significantly reduced the incidence of gray mold in CA-stored d'Anjou pear fruit. In the Pacific Northwest, benzimidazole fungicides have not been recommended for use in the orchards after the occurrence of resistance of Penicillium expansum to benomyl in the 1970s (2). In Washington State, only $<3 \%$ of $B$. cinerea isolates collected from apple from 2001 to 2003 were resistant to TBZ (C. L. Xiao, unpublished data). This may explain why a low level of gray mold was observed in TBZ-drenched fruit. In contrast, there was a significantly higher percentage of blue mold in TBZdrenched fruit in the total decay than in the nondrenched fruit. This is consistent with previous reports that resistance of $P$. ex- pansum to TBZ often resulted in the failure of blue mold control $(5,21,23)$. The suspension in the drench tank is one of the major sources of $P$. expansum inoculum for infection of apple fruit by the pathogen because commercial packinghouses recycle drenching water in which Penicillium spores are accumulated over time (22). Our observations are in agreement with those of Sanderson and Spotts (25), who reported that spores of Penicillium are often recovered from drench solutions and that drenched fruit has a higher level of blue mold than nondrenched fruit. The pattern of occurrence of postharvest diseases we found in this study may be altered when new postharvest fungicides are used. Fludioxonil and pyrimethanil were registered in late 2004 in the United States for postharvest use on pome fruits. The two new postharvest fungicides are very effective in controlling $P$. expansum and $B$. cinerea in apple $(7,16,26)$ as well as $S$. pyriputrescens in apple (C. L. Xiao, unpublished). The impact of the new postharvest fungicides on the occurrence of postharvest diseases at the commercial scale remains to be determined.

Control of postharvest diseases is a challenging task because multiple diseases need to be targeted in order to provide decay-free or decay-limited fruit to the market. Identifying target pathogens is the first necessary step for development and implementation of relevant measures for disease control. The survey results indicate that in addition to blue mold and gray mold, Sphaeropsis rot should also be considered one of the target diseases in stored apples in Washington State.

\section{ACKNOWLEDGMENTS}

Plant Pathology New Series 0472, Department of Plant Pathology, College of Agricultural, Human, and Natural Resource Sciences Agricultural Research Center, Project No. WNP00367, Washington State University, Pullman, WA 99164-6430, USA. We thank the packinghouses involved in the survey for assistance with sampling and R. J. Boal and L. J. Stone for technical assistance. This research was supported in part by the Washington Tree Fruit Research Commission.

\section{LITERATURE CITED}

1. Barnett, H. L., and Hunter, B. B. 1998. Illustrated Genera of Imperfect Fungi. 4th ed. American Phytopathological Society, St. Paul, MN.

2. Bertrand, P. F., and Saulie-Carter, J. L. 1978. The occurrence of benomyl-tolerant strains of Penicillium expansum and Botrytis cinerea in the Mid-Columbia region of Oregon and Washington. Plant Dis. Rep. 62:302-305.

3. Blankenship, S. M., and Dole, J. M. 2003. 1Methylcyclopropene: A review. Postharv. Biol. Technol. 28:1-25.

4. Carmichael, J. W., Kendrick, W. B., Conners, I. L., and Sigler, L. 1980. Genera of Hyphomycetes. University of Alberta, Edmonton, Alberta, Canada.

5. Eckert, J. W. 1988. Dynamics of benzimidazole-resistant Penicilla in the development of postharvest decays of citrus and pome fruits. Pages 31-35 in: Fungicide Resistance in North America. C. J. Delp, eds. American Phytopathological Society, St. Paul, MN.
6. Edney, K. L. 1983. Top fruit. Pages 43-71 in: Post-Harvest Pathology of Fruits and Vegetables. C. Dennis, ed. Academic Press, New York.

7. Errampalli, D. 2004. Effect of fludioxonil on germination and growth of Penicillium expansum and decay in apple cvs. Empire and Gala. Crop Prot. 23:811-817.

8. Fan, X., Blankenship, S. M., and Mattheis, J. P. 1999. 1-Methylcyclopropene inhibits apple ripening. J. Am. Soc. Hortic. Sci. 124:690-695.

9. Fan, X., Mattheis, J. P., and Blankenship, S. M 1999. Development of apple superficial scald, soft scald, core flush, and greasiness is reduced by MCP. J. Agric. Food Chem. 47:3063-3068.

10. Gomez, K. A., and Gomez, A. A. 1984. Statistical Procedures for Agricultural Research. 2nd ed. John Wiley \& Sons, New York.

11. Heald, F. D., and Ruehle, G. D. 1931. The rots of Washington apples in cold storage. Ext. Bull. No. 253, State College of Washington, Pullman.

12. Janisiewicz, W. J., Leverentz, B., Conway, W. S., Saftner, R. A., Reed, A. N., and Camp, M. J. 2003. Control of bitter rot and blue mold of apples by integrating heat and antagonist treatments on 1-MCP treated fruit stored under controlled atmosphere conditions. Postharv. Biol. Technol. 29:129-143.

13. Kim, Y. K., and Xiao, C. L. 2006. A postharvest fruit rot in apple caused by $P h a$ cidiopycnis washingtonensis. Plant Dis. 90:1376-1381.

14. Kim, Y. K., Xiao, C. L., and Rogers, J. D. 2005. Influence of culture media and environmental factors on mycelial growth and pycnidial production of Sphaeropsis pyriputrescens. Mycologia 97:25-32.

15. Lennox, C. L., Spotts, R. A., and Booyse, M. 2004. Incidence of postharvest decay of 'd'Anjou' pear and control with a thiabendazole drench. Plant Dis. 88:474-478.

16. Li, H. X., and Xiao, C. L. 2008. Baseline sensitivities to fludioxonil and pyrimethanil in Penicillium expansum populations from apple in Washington State. Postharv. Biol. Technol. 47:239-245.

17. Meheriuk, M. 1993. CA storage conditions for apples, pears, and nashi. Pages 819-841 in: Proc. Int. Controlled Atmosphere Res. Conf. 6th. Cornell University, Ithaca, NY.

18. Mitcham, E. J., and Mitchell, F. G. 2002. Postharvest handling systems: Pome fruits. Pages 333-344 in: Postharvest Technology of Horticultural Crops. 3rd ed. A. A. Kader, ed. University of California, Agriculture and Natural Resources, Pub. 3311, Oakland, CA.

19. National Agricultural Statistics Service, 2002. 2002 Washington Agricultural Statistics.

20. National Agricultural Statistics Service, 2005. 2005 Washington Agricultural Statistics.

21. Prusky, D., Bazak, M., and Ben-Arie, R. 1985. Development, persistence, survival, and strategies for control of thiabendazole-resistant strains of Penicillium expansum on pome fruits. Phytopathology 75:877-882.

22. Rosenberger, D. A. 1990. Blue mold. Pages 54-55 in: Compendium of Apple and Pear Diseases. A. L. Jones and H. S. Aldwinckle, eds. American Phytopathological Society, St. Paul, MN.

23. Rosenberger, D. A., Wicklow, D. T., Korjagin, V. A., and Rondinaro, S. M. 1991. Pathogenicity and benzimidazole resistance in Penicillium species recovered from flotation tanks in apple packinghouses. Plant Dis. 75:712-715.

24. Saftner, R. A., Abbott, J. A., Conway, W. S., and Barden, C. L. 2003. Effects of 1Methylcyclopropene and heat treatments on ripening and postharvest decay in 'Golden Delicious' apples. J. Am. Soc. Hortic. Sci. 128:120-127.

25. Sanderson, P. G., and Spotts, R. A. 1995. Postharvest decay of winter pear and apple 
fruit caused by Penicillium. Phytopathology 85:103-110.

26. Sholberg, P. L., Bedford, K., and Stokes, S. 2005. Sensitivity of Penicillium spp. and Botrytis cinerea to pyrimethanil and its control of blue and grey mold of stored apples. Crop Prot. 24:127-134.

27. Sholberg, P. L., and Haag, P. D. 1996. Incidence of postharvest pathogens of stored apples in British Columbia. Can. J. Plant Pathol. 18:81-85.

28. Spotts, R. A. 1990. Bull's-eye rot. Pages 56 in: Compendium of Apple and Pear Diseases. A. L. Jones and H. S. Aldwinckle, eds. American Phytopathological Society, St. Paul, MN.

29. Spotts, R. A. 1990. Mucor rot. Pages 57-58 in: Compendium of Apple and Pear Diseases. A. L. Jones and H. S. Aldwinckle, eds. American
Phytopathological Society, St. Paul, MN.

30. Spotts, R. A., Sholberg, P. L., Randall, P., Serdani, M., and Chen, P. M. 2007. Effects of 1-MCP and hexanal on decay of d'Anjou pear fruit in long-term cold storage. Postharv. Biol. Technol. 44:101-106.

31. Sutton, B. C. 1980. The Coleomycetes. Commonwealth Mycological Institute, Kew, England.

32. Sutton, T. B. 1990. Black rot. Pages $18-20$ in: Compendium of Apple and Pear Diseases. A. L. Jones and H. S. Aldwinckle, eds. American Phytopathological Society, St. Paul, MN.

33. Xiao, C. L. 2007. Newly recognized postharvest fruit rot diseases of apple and pear in the U.S. Pacific Northwest. (Abstr.) Phytopathology $97:$ S171

34. Xiao, C. L., and Boal, R. J. 2004. Prevalence and incidence of Phacidiopycnis rot in d'Anjou pears in Washington State. Plant Dis. 88:413-418.

35. Xiao, C. L., and Kim, Y. K. 2005. Decay control with new tools. Proc. Washington State Hortic. Assoc. 100th Annu. Meet. pp. 169-175.

36. Xiao, C. L., and Rogers, J. D. 2004. A postharvest fruit rot in d'Anjou pears caused by Sphaeropsis pyriputrescens sp. nov. Plant Dis. 88:114-118.

37. Xiao, C. L., Rogers, J. D., and Boal, R. J. 2004. First report of a new postharvest fruit rot on apple caused by Sphaeropsis pyriputrescens. Plant Dis. 88:223.

38. Xiao, C. L., Rogers, J. D., Kim, Y. K., and Liu, Q. 2005. Phacidiopycnis washingtonesis - A new species associated with pome fruits from Washington State. Mycologia 97:464-473. 